\title{
New directions of foreign direct investment and industrial development
}

Link to publication record in Manchester Research Explorer

\section{Citation for published version (APA):}

Yamin, M., Nixson, F., Weiss, J. (Ed.), \& Tribe, M. A. (Ed.) (2016). New directions of foreign direct investment and industrial development. In Routledge handbook of industry and development (pp. 166-183). Routledge.

http://www.worldcat.org/oclc/907966091http://www.tandf.net/books/details/9780415819695/

\section{Published in:}

Routledge handbook of industry and development

\section{Citing this paper}

Please note that where the full-text provided on Manchester Research Explorer is the Author Accepted Manuscript or Proof version this may differ from the final Published version. If citing, it is advised that you check and use the publisher's definitive version.

\section{General rights}

Copyright and moral rights for the publications made accessible in the Research Explorer are retained by the authors and/or other copyright owners and it is a condition of accessing publications that users recognise and abide by the legal requirements associated with these rights.

\section{Takedown policy}

If you believe that this document breaches copyright please refer to the University of Manchester's Takedown Procedures [http://man.ac.uk/04Y6Bo] or contact uml.scholarlycommunications@manchester.ac.uk providing relevant details, so we can investigate your claim.

\section{OPEN ACCESS}


Yamin, Mo and Frederick Nixson (2016), "New directions of foreign direct investment and industrial development," in Routledge handbook of industry and development, John Weiss and Michael A. Tribe (Eds.). Abingdon, Oxon: Routledge, 166-183.

10

\title{
NEW DIRECTIONS OF FOREIGN DIRECT INVESTMENT AND INDUSTRIAL DEVELOPMENT
}

\author{
Mo Yamin and Frederick Nixson
}

\section{Introduction}

Although they appear to be separate bodies of literature, and indeed are usually treated as such, there are in fact strong continuities and synergies between the largely critical heterogeneous literature of the 1960s and 1970s on foreign direct investment (FDI), multinational corporations (MNCs) and economic development, and the contemporary international business (IB) literature. In this context, this chapter has two basic objectives.

First, it presents a brief historical overview of how economists have attempted to deal with and understand the complex relationships between FDI and economic development, within a global economy which is itself undergoing fundamental transformations. Within this context, it attempts to identify issues that remain of importance for economic development within the contemporary global economy but which are in danger of not getting the attention that they deserve. The issues that remain on the 'development agenda' are: linkage creation (largely but not only within the context of global value chains (GVCs) (Kaplinsky, 2005 and Chapter 11, this volume); tax minimisation strategies, involving, inter alia, the manipulation of intra-corporate transfer prices (as identified by Vaitsos, 1974); conflicts of interest both within GVCs (given much emphasis in the relevant literature) and between MNCs more generally and the interests of host country governments or economic development broadly defined; technological development (no longer a discussion of 'appropriate technology' but often described as 'green technology'). Almost totally forgotten or ignored is the discussion of FDI as one dimension of oligopolistic competition (Knickerbocker, 1973; Yamin, 1983). Finally, the importance of industrial policy is returning to the development agenda, admittedly having been kept alive by, among others, Lall (1992, 2003); Chang (2003); Lin and Chang (2009); and Weiss (Chapter 8, this volume).

Second, the chapter presents an overview of the contemporary IB literature on the foreign investment activities of MNCs, highlighting a number of implications for the process and nature of economic development. The discipline of IB has naturally focused on the firm or the business as the focal unit of analysis and for a long time, inquiries beyond the firm as the unit of analysis, including its potential developmental impacts, were not in the core domain of IB. Nevertheless, since the 1970s, many writers have assumed that MNCs, by utilising their superior technological and other ownership advantages would in most cases impart significant 
economic benefits to host developing countries (a view challenged by heterodox, structuralist, neo-Marxist and dependency theorists, discussed in the following section). The orthodox view sees MNCs as 'engines of growth' (UNCTAD, 1992 for example).

This view has more recently become more qualified and the earlier optimism has tended to be replaced with a general realisation that the positive developmental impacts of FDI are not automatic, and that a reassessment of the impact must start with the recognition that the direction, purpose and impact of FDI is largely dependent on the strategy of the MNCs. In this chapter we argue that MNC strategies have undergone major changes and are currently not so much 'market seeking', but are rather mainly 'efficiency seeking', where access to cheap labour and other assets is a major driver of the investment. The large literature on linkage creation and assumed spill-over effects is directly relevant to any assessment of the impact of FDI on economic development (discussed in the fourth section). Although the notion of spill-overs has had a rather seductive appeal for advocates of FDI as a key input in the development process, the experience of most host developing economies has not been unambiguously positive in this respect.

The above discussion has so far implicitly focused on the more developed country MNCs (henceforth DMNCs), and on developing rather than 'emerging' host economies (see the third section below for a broad definition). The latter category of countries complicates the situation for at least two reasons. As hosts for DMNCs the situation in emerging economies increasingly demands that DMNCs must become 'strategic insiders' and correspondingly commit themselves to a longer-term engagement with these economies (Luo, 2007).

But it must also be recognised that 'emerging economies' are increasingly the home economies of MNCs (henceforth referred to as EMNCs). EMNCs possess distinctive capabilities and follow distinctive strategies of internationalisation (Ramamurti and Singh, 2009; Amsden, 2009; Williamson et al., 2013). Recent data also confirm that EMNCs have begun significantly to challenge the previously dominant position of DMNCs in terms of their share of outward FDI (including flows to developing and emerging economies (see the third section).

The chapter is structured as follows: the following section reviews the literature from the 1960s through to the early-1980s and draws out what are considered to be the salient issues still relevant at the present time. The third section considers the more recent literature, including the IB literature and discusses the implications of that perspective for economic development. The focus in this section is on a selected number of issues, including the impact of FDI on economic growth, linkage creation and technological development. We argue that the need for selective and effective industrial policies in both 'emerging' and 'developing' economies is as great as it has ever been and we re-introduce and re-emphasise the importance of oligopoly and the nature of oligopolistic competition into the discussion.

\section{A brief historical overview}

At the outset it is useful to point out that contributors to the 'old' literature, irrespective of their differing standpoints, implicitly regarded MNCs and FDI outflows to be almost exclusively a developed economy phenomenon. There was a small literature that looked at the 'third world multinationals' (Lall, 1982) but these were small players and did not seriously challenge DMNCs. Thus in practical terms, the literature relating to the impact of FDI and development was overwhelmingly about the investment activities of DMNCs.

The impact of the DMNCs on economic development through FDI and technology transfer has always excited controversy and passionately held opposing views. The seminal work of Hymer (1976) argued that the ability to undertake FDI and other forms of international 
operations' were rooted in oligopolistic market power and that the key driver for international expansion was the retention of control over markets. Although Hymer's views have remained influential (Yamin, 2000), the dominant, orthodox, view has been that DMNCs were a response to 'natural' market imperfections largely rooted in transactions costs (Buckley and Casson, 1976). From this orthodox perspective, many writers (for example, Hood and Young, 1979) argued that the rise of DMNCs made possible the optimal use of global resources, and that the contribution that they could make was vital for the rapid growth and development of all economies. The rise of the DMNC was seen as a consequence of imperfections in both goods and factor markets, especially in the market for knowledge, and that the overcoming of such imperfections through the creation of internal markets within MNCs through FDI would permit the more efficient exploitation of global comparative advantage, allowing greater international specialisation and an increase in world economic welfare.

On the other hand, development economists of a largely heterodox outlook (including under this heading structuralists, dependency theorists and neo-Marxists) over a period covering approximately the late-1960s to the early-1990s, raised a number of key issues which remain of some concern in the 'age of globalisation'. At the radical end of this spectrum were those who argued that MNCs were the most important aspect of the imperialist penetration of the less developed countries (LDCs), heightening their dependency on the developed capitalist economies and deepening the process of dependent development. There was little unanimity among the more radical critics, however, and MNCs were variously alleged to underdevelop, to distort or block the development of the host less developed economy (Colman and Nixson, 1994: 342). We return to these arguments below.

Between these competing schools of thought were those economists who emphasised the potential contribution of DMNCs to development, but also recognised the impact of actual or potential conflict of interests on the distribution of the benefits and costs of FDI between the parent DMNC and the host economy. It was argued that within a modified global framework (an internationally negotiated Code of Conduct agreed to by DMNCs) and working within an agreed set of guidelines and rules, the MNC, through its ownership and control over technology, capital and marketing and managerial skills could make a unique contribution to the development effort. In other words, FDI was not a zero sum game - both sides could benefit but the distribution of the benefits (and costs) depended on the bargaining strength of the two sides.

From the huge literature that these competing theoretical perspectives and empirical studies generated, we can list what we consider to be the main issues and focal points of dispute:

- Why do LDCs want FDI? What does FDI provide that they lack or have an inadequate supply of?

- What effect does FDI have on the market structures (especially the manufacturing sector) of LDCs? Why is this important?

- Do DMNCs create linkages with other companies within the host LDC? Are those linkages with the subsidiaries of other DMNCs or with locally owned companies? If linkage creation is not adequate, what policies can LDC governments pursue to rectify the situation?

- How much net employment does FDI create? Does FDI have a positive or negative effect on other enterprises/sectors of the host economy? How can host country governments increase employment creation by DMNCs?

- Do DMNCs utilise or transfer labour- or capital-intensive technologies to host LDCs? What factors influence the types of technologies actually transferred by DMNCs? What is the real cost of those technologies and how are they paid for? Will the use of DMNC 
technologies lead to 'technological dependence' and if so, what are the implications of this situation for sustained economic development and industrialisation?

- Should LDCs attempt to develop their own labour-intensive, 'appropriate' or 'intermediate' technologies?

- What is the impact on the host economies' balance of payments (BoPs) of FDI over time? How import-intensive is FDI in general? Do DMNCs encourage the export of manufactured goods? If not, why not? What impact, over time, does FDI have on the capital account of the host economies' BoPs? That is, does FDI actually increase the capital available for investment in the host economies, does it utilise local capital already available or does FDI lead to a drain of capital from the host economy (the de-capitalisation of the economy or a drain of surplus in neo-Marxist terminology)? What are the channels through which capital is 'drained' from the host economy? How important is the manipulation of transfer (intra-corporate) prices within the DMNC, used to avoid controls on the repatriation of profits, or as part of a global tax minimisation strategy?

- How profitable are DMNC activities in LDCs? Are they net contributors to government revenue or are the incentives/subsidies that governments might offer worth more than offset taxes paid?

- Does import substituting (or domestic market oriented) FDI lead to a transfer of tastes, creating a demand for luxury or 'inappropriate' products, with implications for patterns of consumption and income distribution in the host economy? Who is to decide what an 'inappropriate' product is?

- What are the implications for economic development of the emergence of MNCs from LDCs (highlighted for example, by Lall, 1982)? Would FDI by LDC MNCs have a more beneficial impact on the development process? This is an issue of special importance in the contemporary global economy (see the fourth section).

- What are the main conflicts of interest between DMNC parent companies and host LDC governments? Who will benefit most from the eventual resolution of such conflicts? What role might global codes of conduct play in conflict resolution and would such codes alter the balance of power between the two sides in favour of the LDCs?

The answers given to these questions were rarely definitive, unambiguous and acceptable to the majority of economists working in development. The questions posed, and the answers given, were largely influenced by the schools of thought and ideological perspectives within which they were framed. The orthodox, mainly neo-classical school of thought, from the mid-1970s onwards, emphasised the economic benefits of free markets (both for the factors of production and commodities) and minimum 'interference' by governments in those markets. Increasingly as the 1980s progressed, this view led to policies of trade liberalisation, privatisation, liberalisation of capital flows and other supply-side measures aimed at freeing 'market forces'. Less attention was paid to the developmental impact of FDI, and DMNCs were unambiguously regarded as a 'good thing'.

As noted above, on the opposite side of the ideological barricades, structuralists, dependency theorists and neo-Marxists challenged many of these received ideas. From approximately the mid-1950s onwards, into the early-1990s, as we noted above, the various radical/heterodox schools of thought questioned the impact of FDI and were critical of the nature of the development process emerging. From Baran (1957) onwards, through the work of such writers as Frank (1967), Sunkel (1969, 1973), (Dos Santos (1973), Palma (1978) and Cardoso and Faletto (1979), there emerged a variety of critiques of 'dependent development' or 'underdevelopment' , particularly associated with the work of Frank (1967) in which FDI/the DMNC played a leading 
role. Much of this work has been marginalised (or forgotten) by the continuing transformation of the global economy (see the fourth section), but some of the issues raised have re-emerged often under a different guise ('globalisation') or rediscovered in their original role.

From this perspective, we identify four areas of current concern:

- $\quad$ linkage creation (largely but not solely within the context of GVCs);

- issues related to the taxation of MNCs' profits and transfer pricing;

- conflicts of interest and changing bargaining powers and strategies;

- technological development.

The discussion of these issues raises the question of the role of industrial policy which we address below.

\section{Global transformations: Changing strategies of DMNCs and the rise of EMNCs}

The 'old' literature on the FDI-development nexus was largely informed by the debates and analytical frameworks of development studies: the strategies and structures of the organisations that undertook FDI - namely MNCs - were not a focal point of interest and did not receive detailed attention. By contrast, the IB perspective has a narrative that is mainly focused on the strategy and structural attributes of the MNC. As already noted, initially this literature largely ignored issues relating to host country impact and development, although there has been a partial change in this respect. In any case, it is our belief that understanding MNC strategy is necessary in terms of evaluating the impacts of FDI inflows. In particular, it is clearly important to consider the main changes in the global economic landscape since the last decades of the twentieth century. In part this is because 'globalisation', arguably the key aspect of global transformation in the last two to three decades, has complex and 'non-linear' impact effects vis-à-vis FDI flows. Broadly, it is necessary to differentiate between different groups of 'non-advanced' economies - namely less developed and 'emerging' countries (see below). Even more important, the emergence of EMNCs is a new element in any assessment of the impact of FDI flows on recipient countries, even though there is as yet little systematic empirical evidence on the impact of EMNC FDI flows on other emerging and less developed countries.

Accordingly, in this section we first consider the impact of globalisation on the strategies and structure of incumbent DMNCs. We follow this by broadly considering the impact of FDI flows to LDCs. We then consider the emergence and growth of a 'new breed' of MNCs based in emerging economies - the EMNCs.

\section{Globalisation and the DMNCs}

International business theory has argued that established or mature MNCs (DMNCs) confront a strategic tension between the need to adapt to the economic and institutional specificities of individual countries on the one hand, and benefiting from global integration on the other (Bartlett and Ghoshal, 1987). The need for national responsiveness, in part, has reflected an environment in which national governments, especially in less developed economies, had significantly more bargaining power in their dealings with DMNCs than they generally do today. The degree of bargaining power that national governments could exert was mainly dependent on how attractive their market was to potential incoming FDI, which in turn was a function of the size and the growth rate of their economies. However, compared to the present situation, 
all national governments had more policy scope to regulate access to the national economy and, in particular their markets.

Multinational expansion frequently took the form of establishing 'miniature replicas', i.e. subsidiaries which performed several value chain activities in an integrated way and whose main function was to adopt or adapt the products and technologies of the DMNC to the market and customer environment of the host countries. In the context of LDCs, 'miniature replicas' constituted a significant component of import substituting industrialisation (ISI) often behind protectionist barriers erected by governments. From the perspective of economic development, this 'old model' of (DMNC) expansion had a positive quality (Hirschman 1968 and Nixson Chapter 9 in this volume) - compared to what has replaced it - in encouraging linkages in the domestic economy and the development of industrialisation, although in practice the model's implementation was often mired in excessively protectionist policies.

Globalisation has brought a shift in the strategy and structure of multinationals. Two key drivers of globalisation have been the extensive liberalisation of trade and investment policies which have lowered the barriers to cross-border operations, and technological developments, particularly in the realm of information and communication technologies (ICT).

Since the early-1990s there has been a more or less uninterrupted process of lowering restrictions on FDI flows, especially the adoption of policies that promote FDI inflows. The change in policy stance has been particularly dramatic for less developed and emerging countries (see Table 10.1 and Figure 10.1).

Second, advances in technology, primarily through the application of ICT, have increased the scope for production modularity and facilitated a more effective management of the supply chain, wherein the imperatives for vertical integration via direct ownership have been significantly reduced. Leading DMNCs in many sectors have taken on the role of 'system integrators' whereby they increasingly focus on planning and coordinating the supply chain, rather than direct manufacture. The traditional ownership-based structures have been replaced with a complex and variegated web of relationships (UNCTAD, 2013: 143; Gereffi et al., 2005). However, the relationships with core suppliers are far from being 'arms- length'. Nolan and co-authors $(2002,2008)$ show that in industries as diverse as aerospace, automobiles, telecom services and equipment, and beverages, the leading DMNCs ('system integrators') put intense pressure on leading (first tier) suppliers to invest large amounts in R\&D to meet the assemblers' needs. The leading suppliers are invariably also large MNCs in their own right and transmit cost-reduction pressures further down the value chain. Thus contrary to suggestions that globalisation has led to a weakening of the 'visible hand' of corporate integration and control (Langlois, 2003), the advances in ICT and production modularity do not necessarily or unambiguously favour

Table 10.1 The dominance of pro-FDI policies in emerging and developing countries, 1991-2000

\begin{tabular}{|c|c|c|c|c|c|c|c|c|c|c|}
\hline & 1991 & 1992 & 1993 & 1994 & 1994 & 1996 & 1997 & 1998 & 1999 & 2000 \\
\hline \multicolumn{11}{|l|}{$\begin{array}{l}\text { Number of countries that } \\
\text { introduced changes in their }\end{array}$} \\
\hline investment regimes & 35 & 43 & 57 & 49 & 64 & 65 & 76 & 60 & 63 & 69 \\
\hline Number of regulatory changes & 82 & 79 & 102 & 110 & 112 & 114 & 151 & 145 & 140 & 150 \\
\hline \multicolumn{11}{|l|}{ Of which: } \\
\hline More favourable to FDI & 80 & 79 & 101 & 108 & 106 & 98 & 135 & 136 & 131 & 147 \\
\hline Less favourable to FDI & 2 & 0 & 1 & 2 & 6 & 16 & 16 & 9 & 9 & 3 \\
\hline
\end{tabular}

Source: UNCTAD (2001: 6). 


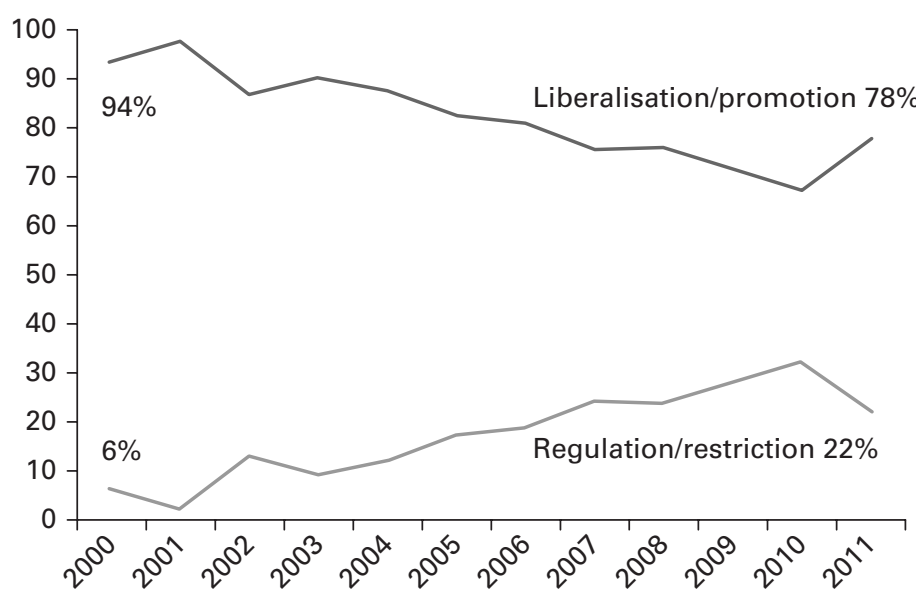

Figure 10.1 National regulatory changes, 2000-2011 (per cent).

Source: UNCTAD (2012: 76).

markets or relational contracting (Perrow, 2009); they can and do also enhance the ability of the visible hand, wielded by the system integrators to effectively coordinate a chain or network of independent but captive suppliers and service providers across many national borders. Other important recent contributions have also noted the growing control capabilities of leading DMNCs, pointing out that planning by the lead firms rather than ownership is the key criterion for delineation of firm boundaries (Buckley, 2009; Yamin, 2011).

Overall, the most important consequence of globalisation for DMNC strategy is that it has significantly enhanced strategic flexibility in terms of much greater locational choices as well as ownership policies. In the 'old', vertically integrated, structures much of the HQ's resources and energy was taken up by the organisational tussle with powerful and entrenched subsidiaries (Buckley and Ghauri, 2004; Yamin and Forsgren, 2006). The new structure has enhanced the power of the centre vis-à-vis subsidiaries and has, as a consequence, given the HQ greater scope and ability to effectively pursue 'asset seeking' strategies in addition to the 'efficiency seeking' (cost minimisation) strategies. In particular, DMNCs monitor and access strategic assets from 'dynamic' locations. Emerging markets are perceived as 'hard' to understand and yet they generate 'unconventional' innovative capabilities (Bhattacharya et al., 2013) and have induced DMNCs to seek 'insider' positions in key business and policy/political networks within emerging markets (Luo, 2007).

\section{FDI impacts on less developed countries}

The current and somewhat variegated patterns of MNC involvements in emerging and less developed countries, whether through FDI or other 'non-equity' modalities, can only be understood in the context of the broader changes, indicated briefly above, in the strategy and structure of leading DMNCs. Consistent with this, the pattern of FDI flows to less developed countries is influenced by the fact that host countries fit into the strategic calculation of DMNCs as sites for resources rather than markets. This does not mean that DMNCs are not interested in markets but that, owing to low trade barriers, market access is no longer a major issue. Most LDCs have attracted FDI that entails the transfer of low technology and low value activities to be combined with the main location-bound advantages of these countries - cheap and unskilled labour, often 
with additional incentives offered by host governments such as tax exemptions (UNCTAD, 2003). FDI flows to LDCs are associated with LDC participation in DMNC-controlled production networks. LDCs usually enter these networks as 'junior' partners, as second and more frequently third tier suppliers, and therefore as sites for the production of a highly specified and narrow range of low value-adding activities.

Recent studies, focusing on the impact of FDI flows on economic growth in recipient LDCs, suggest at best ambiguous results with a weak or zero effect on economic growth (Narula and Driffield, 2012; Beugelsdijk et al., 2008). One solid, consistent finding is the relevance of domestic absorptive capacity in recipient countries in the generation of positive productivity or growth effects (for example Xu, 2000; Crespo and Fontura, 2007). This in turn highlights the relevance of a strong infra-structure, especially in terms of cumulative investment in education and training (Yamin and Sinkovics, 2009).

The literature on spill-over effects of FDI in LDCs is consistent with the weak or ambiguous growth effects of FDI. Spill-overs are the 'external economy' associated with FDI: they can generate benefits that are not fully captured by the DMNC undertaking the investment. Thus in theory LDC firms gain productivity and knowledge advantages that they do not pay for in full (Zanfei, 2005). The mechanisms through which spill-overs can occur have been discussed at length in the literature (see for example Bloomström et al., 2000; Kokko et al., 2001) and include learning by doing and knowledge transfer to domestic firms and enhanced productivity growth through greater competition induced by the entry of the DMNC. The focus on the extent and depth of DMNC linkages in the host economy reflects an expectation of the enhanced possibility of knowledge and productivity benefits accruing to the DMNCs' local partners at a lower cost than would otherwise be the case. However, such an outcome is not automatic (Meyer and Sinani, 2009). The literature suggests only a positive correlation rather than a definite causal relationship between linkages and spill-overs. Generally, the greater the degree of an DMNCs' resource commitment to the host economy, through linkages and sourcing of intermediate inputs (Rodriquez-Clare, 1996), the greater the degree of positive spill-overs likely to occur in LDCs.

Only a few studies have examined DMNC affiliates in LDCs for the pattern of their linkages in host countries (UNCTAD, 2001). Available aggregate data on FDI flows relating to the last decades of the twentieth century provide clear indications that, although there was a very large influx by DMNCs into LDCs, these typically resulted in extremely 'shallow' levels and types of investment in these countries with a low or absent potential for positive spill-overs. Thus there is a sharp disparity between the shares of LDCs in inward FDI stocks/ flows by DMNCs on the one hand and their share of the number of foreign affiliates on the other. According to the World Investment Report (UNCTAD, 2001), 51.5 per cent of all DMNC affiliates were located in LDCs in the year 2000, accounting for only 24 per cent of FDI inflows. The developed countries by comparison accounted for 14 per cent of all affiliates but 73 per cent of FDI inflows (UNCTAD, 2001). The magnitude of the disparity is partly due to a change in the structure of DMNC activity in many LDCs, away from a focus on local markets (which would entail greater investment in support of integrated local production) and towards their incorporation into the rationalised global production networks that they control.

Studies focusing on individual LDCs conform to the above picture. A study by Edwards, Ahmad and Moss (2002) on DMNC subsidiaries in Malaysia shows that subsidiaries have low levels of decision-making autonomy and low integration into the Malaysian economy. Mirza and Giroud (2004), focusing on Vietnam, report very similar findings. Studies specifically focusing on linkages have generally observed that indigenous local firms are usually second or third, rather than first, tier suppliers vis-à-vis DMNCs (e.g. Sanchez-Ancochea, 2006). Luo's (2004) 
study of the determinants of resource commitments in emerging economies shows that resource commitment is lower when DMNC strategies stress cost rather than demand-side gains. A more recent study (Morrissey, 2012) provides strong confirmation of this in that where FDI is motivated by cost or efficiency motives rather than by market development, the linkage and spill-over effects are weak or non-existent. We will return to this issue of linkages in the next main section.

\section{The rise of multinationals from emerging markets (EMNCs)}

As we have already noted, an important feature of the contemporary global economic environment is that 'non-advanced' economies constitute more heterogeneous categories than has hitherto been the case, although lumping all non-advanced countries as 'the third world' or even as 'less developed' was never very accurate. However, it is probably the case that globalisation has accentuated such heterogeneities. The main distinction between 'emerging' and 'less developed' countries is that, compared to 'less developed countries', emerging countries benefit from a relatively long history of (import substituting) industrialisation and have gained greater technological skills - production and project execution capabilities as well as a modicum of innovation capabilities (Amsden, 2001; 2009). They also have more capable governments with a more assertive stance with respect to negotiating with DMNCs, and have for long followed mixed economy policies significantly at odds with the prescriptions of the 'Washington Consensus' (Fourcade, 2013). Broadly, emerging economies are considered to be 'catching up' with advanced economies while the rest ('less developed') are either not catching up or are even 'falling behind' (Dunning and Narula, 2004). As noted already, emerging economies have been a major destination for FDI flows and are considered as important not only as offshoring sites but also as strategic locations in terms of future market growth. According to the World Investment Report (UNCTAD, 2014) emerging economies occupy top positions as prospective markets for DMNCs' future investments (see Figure 10.2). It is also noteworthy that 'south-south' FDI flows have increased at a rapid pace over the last two decades, now accounting for 45 per cent of all FDI inflows into developing countries (see Figure 10.3). For the BRICS (Brazil, Russia, India, China and South Africa) the percentage of FDI flows to LDCs is 50 per cent (UNCTAD, 2013: 5).

The IB literature has paid growing attention to the rise and to the rapid growth of EMNCs, particularly those based in the larger emerging economies and notably the BRICS (Ramamurti and Singh, 2009; Williamson et al., 2013).

Much of this discussion focuses on whether EMNCs are really 'different' from DMNCs, and thus whether new theories or concepts are needed to understand them. However, their development impact has not been a focal part of these discussions. Nevertheless a growing number of case studies have suggested that a significant portion of EMNCs may have capabilities and are relatively development 'friendly'. In fact recent research is suggestive of 'transformative' capabilities for some EMNCs in terms of upsetting the dominant 'rules of the global competition game' (Sinkovics et al., 2014).

Specifically, it has been argued that EMNCs have capabilities that better "match the requirements of the new global environment" (Gao, 2011: 541). An important aspect of the new global economic environment is indeed the very rapidly growing domestic markets of emerging economies where the vast majority of the population is poor by developed country standards but who nevertheless constitute important markets - this being particularly true of China and India. The growing size of the low and middle income segments in the emerging economies 


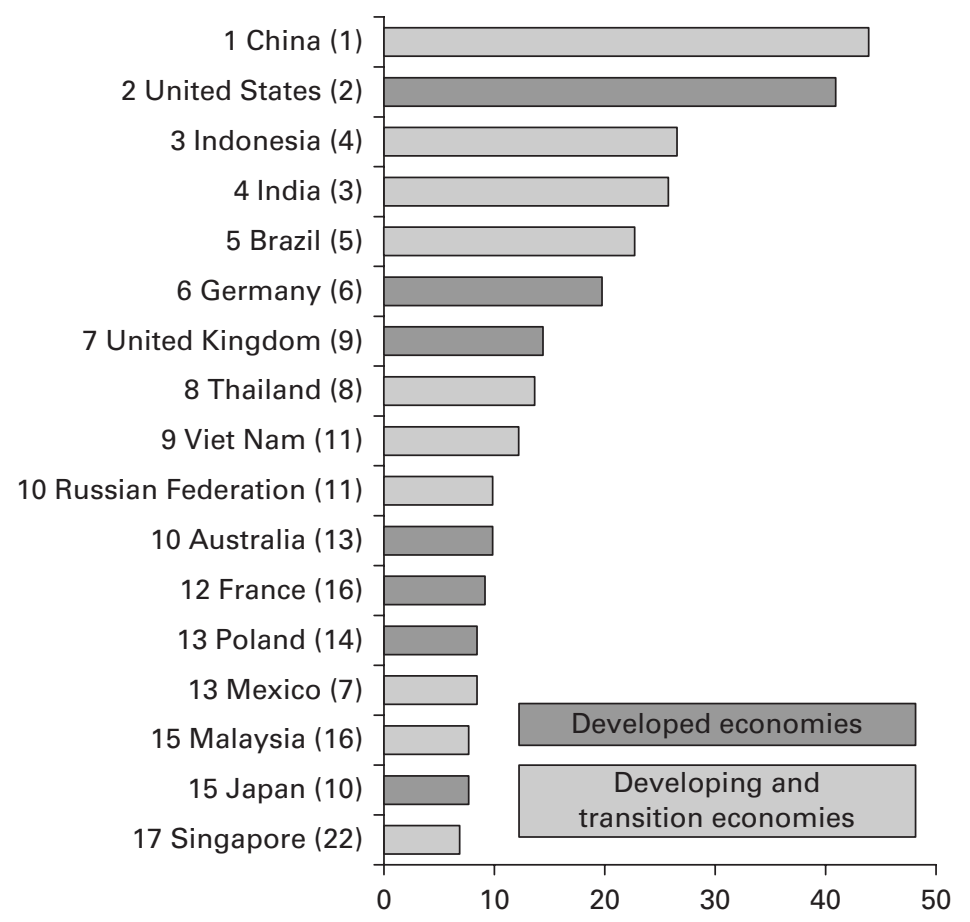

Figure 10.2 MNCs top prospective markets for 2014-2016 (\% of respondents selecting market as top destination). $(\mathrm{X})=2013$ ranking.

Source: UNCTAD (2014: 28).

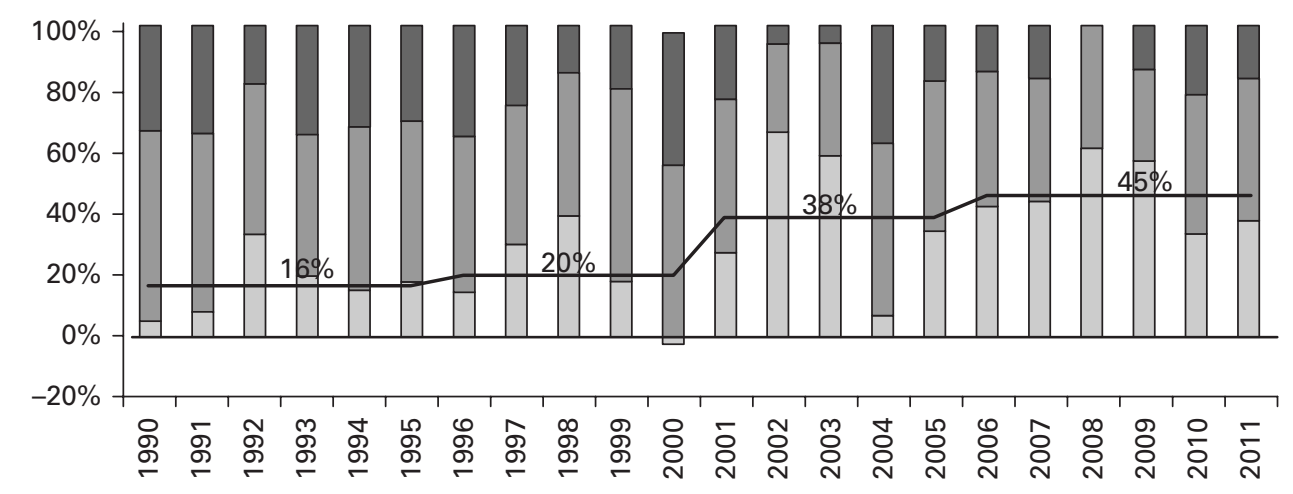

\begin{tabular}{|ll|}
$\square$ South-South & $\square$ From high-income OECD \\
$\square$ From high-income non-OECD & South-south period average \\
\hline
\end{tabular}

Figure 10.3 FDI inflows in south countries (percentage of total, 1990-2011).

Note: South-South FDI is calculated here as a residual after accounting for North inflows and NorthSouth flows. See methodological notes in the original source for more detail.

Source: IADB (2013: 27), citing IADB Integration and Trade Sector based on UNCTAD, WDI and OECD FDI statistics. 
has enabled EMNCs to generate distinctive capabilities that both challenge the dominance of DMNCs and have arguably 'better' developmental impacts.

In an important study focusing on China, Brandt and Thun (2010) demonstrate that the crucial battleground between DMNCs and EMNCs is increasingly the 'fight for the middle'. EMNCs have a decided advantage over DMNCs in this battle because they have brought forth innovations specifically "targeted at the middle or the base of the economic pyramid" (Williamson et al., 2013: 296) that are perceived by consumers as being 'good enough' (Gadiesh et al., 2007). The distinctive aspect of innovation by EMNCs, particularly for Chinese EMNCs, is cost innovation, that is, innovations that provide advanced technology and good quality products at low cost which are affordable by low and middle income segments in emerging and less developed countries (Williamson et al., 2013: 67-69). The cost innovation and 'good enough' phenomena are not only about consumer goods. For example, in the medical diagnostics devices industry cost innovation has created a greater range of Chinese 'alternative' products priced much more cheaply than those of established foreign competitors (Little, 2008). As a consequence, a vastly expanded market has been developed among second tier hospitals and clinics (typically located in small towns in the hinterland) which were formerly unable to consider this class of equipment due to high costs. As Little (2008: 6) has noted: "The delivery of state-of-the-art-technology to the health system [as a whole] rather than only to leading research and teaching hospitals echoes the bottom of the pyramid sensibility".

The cost innovation capabilities of EMNCs have important implications for LDCs. EMNCs have developed expertise in mass production which they utilise to manufacture technologically standardised products in other emerging and developing markets where the demand for such items is huge. As noted by Luo and Tung (2007), their low-cost advantage enables EMNCs to offer a price that is very attractive to local consumers, thus enabling them to increase their market share vis-à-vis DMNCs that have been there for a long time. This echoes a much earlier debate in the development literature about 'appropriate' products and technologies and the potential benefits of 'south-south' trade and investment flows (Stewart, 1977). The emergence of the new EMNCs may be generating more 'appropriate' FDI flows to less developed countries compared to FDI flows from DMNCs.

\section{Government policy and bargaining issues}

In the second section we identified four broad areas which had attracted much attention and debate in the earlier literature on the developmental impact of FDI: (a) bargaining issues in general, with particular reference to (b) the taxation and transfer pricing strategies of MNCs which have implications both for the generation of government revenue and reinvestment strategies by the MNCs themselves, as well as of course having an impact on the BoPs of host economies; (c) linkage creation; and (d) technological development. We argue that these issues are at least as important today in the contemporary world as they were earlier. We address these issues under two headings: bargaining and taxation issues, and linkages and technological development.

\section{Bargaining and taxation}

The overall impact of globalisation on the bargaining power of LDC governments vis-à-vis MNCs has been complex and somewhat contradictory, in some respects enhancing bargaining power while in other respects undermining it. The complexity arises partly because unlike the earlier periods, bargaining is not necessarily always a dyadic interaction between 
host governments and incoming MNCs. As noted in the previous section, DMNCs have been instrumental in the disaggregation and dispersal of value activities and the formation of global production networks. Given the transnational scope of such networks, each LDC is hosting only a small portion of the overall production chain. Consequently, individual LDC governments' influence in the shaping of the governance of the network is relatively minor. Levy (2008) has argued that global production networks should be conceptualised as politically contested fields within which a number of stakeholders, in addition to governments, seek to exert influence. Non-governmental players, such as NGOs which also possess transnational perspectives, can be effective in capturing limited gains for disadvantaged groups, although fundamental asymmetries are bound to favour the nodal DMNCs (Levy, 2008: 957). Another relevant issue is that DMNCs have shown more ability (compared with LDC governments) to act collectively and to shape the macro-institutional environment in the global economy in their favour. The Uruguay round of the General Agreement on Trade and Tariffs (GATT) and the formation of the World Trade Organisation (WTO) are prime examples (Sell, 2003; Wade, 2003).

On the other hand, the emergence of EMNCs, with their distinctive capabilities and rapidly growing investment, should arguably enhance the bargaining power of governments in recipient LDCs. As we noted in the previous section, EMNCs are actively investing in other emerging and less developed countries with nearly half of all FDI inflows currently (i.e. 2014) being carried out by EMNCs. Thus in a quantitative sense, EMNCs are certainly a significant economic presence in many LDCs. Furthermore, although not all EMNCs' investments in LDCs are necessarily market seeking (Azmeh and Nadvi, 2014), it is at least plausible that, compared to DMNCs, EMNCs' investments in LDCs are, at least in principle, likely to be more market seeking, implying relatively more resource commitment to the local economy. This, per se, will improve the bargaining power of host governments as the investments are likely to be less 'foot-loose'. More obviously, however, the very emergence of EMNCs in various sectors simply enhances the level of competition and hence increases the options available to LDC governments. This echoes an earlier discussion relating to the positive effect of (oligopolistic) competition on the bargaining power of host economies vis-à-vis MNCs (Knickerbocker, 1973; Yamin, 1983).

Nevertheless, even though globalisation may intensify competition, thus enhancing the bargaining power of LDCs, we must take note of the fact that it also makes it easier for MNCs to avoid or 'wriggle out' of regulation. The key change is that enforcement costs with respect to regulation are now arguably higher than before and this imposes greater constraints on countries with weaker public administration infrastructures (Yamin and Sinkovics, 2009). A clear and very important illustration of this is the issue of taxation and transfer pricing. While tax avoidance by MNCs has a very long history (Shaxson, 2011), globalisation has arguably increased the opportunities for it while at the same time making its detection and regulation more demanding. Tax avoidance and transfer pricing practices are now more institutionalised than during the 1970s and 1980s. There are two related reasons for this. First, MNCs (and particularly the mature DMNCs) have greater experience and expertise with managing intra-firm resource transfers and more extensive financial planning capabilities. Arguably, these capabilities are the foundation for 'flexibility', which, as was argued earlier, is now the key plank in the strategy of DMNCs. Second, multinational accounting firms (notably the 'Big Four': Price Waterhouse Cooper, Ernst and Young, Deloitte \& Touche and KPMG) have perfected a large array of complex and opaque 'tax planning' mechanisms for their MNC clients which challenge even the tax authorities of the USA and the UK (Sikka and Willmott, 2013; Palan et al., 2010). The latest aggregate data strongly suggest that tax avoidance or 'planning' is a significant factor influencing the level and the direction of flows of company funds. Offshore finance mechanisms in FDI include mainly offshore financial centres or tax-havens and 'Special Purpose Entities' (SPEs). SPEs have 
been defined as: "Foreign affiliates that are established for a specific purpose (e.g. administration, management of foreign exchange risk, facilitation of financing of investment).... They tend to be established in low tax countries. They have few employees and few non-financial assets" (UNCTAD, 2013: 15).

The 2013 World Investment Report (UNCTAD, 2013: 17) reports very high levels of fund movements during 2012 to and from offshore financial centres $(\$ 90 \mathrm{bn})$ and SPEs $(\$ 600 \mathrm{bn})$. One study estimates the annual revenue loss (during 2006-07) to LDC governments as a consequence of tax avoidance at around $\$ 500 \mathrm{bn}$ of which some $\$ 365 \mathrm{bn}$ is attributed to transfer pricing practices that shift profits from developing to developed countries (Sikka and Willmott, 2013 - citing Kar and Cartwright-Smith, 2008).

IB scholarship recognises, and some contributors even strongly emphasise, that globalisation actually reinforces the role of governments in generating positive impacts from incoming FDI. Thus Dunning and Narula (2004) argue that, rather paradoxically, even though globalisation is associated with greater mobility of knowledge-based 'ownership' advantages of MNCs, the competitive advantages of countries (and firms) increasingly depend on combining mobile assets with 'sticky' locational assets and capabilities. Government policy and support for the development of domestic absorptive capacity is crucial in ensuring positive impacts. Narula and Driffield (2012: 6) imply that governments in many LDCs have been unnecessarily lax in their approach towards incoming FDI, observing that "countries that have taken a 'generic' approach to FDI as a determinant of development have largely been disappointed". This implies that many governments have been slow in recognising that FDI cannot be considered as an automatic 'engine' of development. They have focused more on attracting FDI than on ensuring that benefits actually flow from it.

\section{Linkages and technological development}

Development economists have stressed the important link between technological learning and industrialisation (for example, Amsden, 1989). Technological learning is an evolutionary and incremental process always beset, to varying degrees, by market failure in that it is subject to significant risk, uncertainty, and externalities. These characteristics imply that, especially in the context of developing countries, technological learning processes cannot be left to market forces (Wade, 1990). The experience of the newly industrialised countries in East Asia confirmed the importance of industrial policy in supporting industrialisation and the development of technology capabilities. In particular, Korea and Taiwan followed a set of policies which allowed FDI only in selected sectors and exerted pressures for raising local content, technology diffusion and local subcontracting. Technological development was promoted not only by a set of 'functional' industrial policies (policies that benefit all economic activity) such as investment in education and the infrastructure, but also selective_policies that promoted particular dynamic activities and industries (Lall and Teubal, 1998). The basis of such selectivity was the degree of difficulty of the learning and knowledge acquisition process, which reflected the premise that market forces would provide insufficient support for such activities. Reliance on market forces tends to encourage development along the existing structure of comparative advantage (typically promoting labour-intensive activities).

In the current context, in order to increase domestic value added (especially as part of GVCs), LDCs need to encourage linkage creation with domestic enterprises. Linkage creation is difficult (Lall, 1982) and requires effective government support and some measure of selective industrial policy which are however, more difficult in the context of WTO regulations, especially for smaller LDCs with weaker bargaining power. 
The recent experience of most LDCs is that, in the absence of government pressure or the lure of capturing and securing greater market share in rapidly growing markets, DMNCs are unlikely to encourage linkage formation. LDC involvement in narrow-scope activities as a part of the global production networks has generated few local linkages (Miozzo and Yamin, 2012). The work of Amsden (1989, 2009; Amsden and Hikino, 1994) provides a useful benchmark for evaluating the impact of FDI and other types of involvement on technological progress in LDCs. This work has highlighted three levels of technological learning: production capability, project execution capability and innovative capability. Linkages with DMNCs often result in only limited technological learning, limited to production capability, and have been characterised as 'passive' learning (Nam and Li, 2013). Learning beyond production capability (project execution and innovative capability) requires 'active' learning by local firms and suppliers and is unlikely to be generated through knowledge transfer from global buyers (Nam and Li, 2013; Gentile-Ludeke and Giroud, 2012). Given the uncertainty and risk associated with technological learning, most suppliers are likely to avoid going along such a path unless there is a degree of sustained government support.

As noted above, WTO regulations restrict or prohibit the kinds of selective government support that technological development and effective linkage formation would require. In this connection, it is a useful reminder that WTO rules are somewhat more tolerant of government support for science and technology development than of 'industrial policy' in general. However, in the context of the 'catch-up' process this seems an artificial distinction. LDC learning necessarily requires a large degree of government support for what are now mature or 'traditional' industries or for activities in advanced capitalist countries. Ironically the very governments which are ardent advocates of liberal market policies have been very active in support of their own emerging science-based industries. The development of sectors such as biotechnology, microelectronics, information technology, new materials and nanotechnology has been strongly promoted and subsidised by the EU and US governments (Weiss, 2010). In effect this is industrial policy providing 'infant' industry protection and/or promotion for sciencebased industries (but which is labelled and legitimised as promoting science and technology, and which is therefore permitted by the WTO). Government regulations and industrial policy incentivising/compelling meaningful ('deep') linkage formation are also necessary to support the development of technological capabilities and learning through the development of industries that are infant or adolescent in the LDCs. Restricting this sort of industrial policy in LDCs is an aspect of "kicking away the ladder" (Chang, 2002; see also Weiss, Chapter 8 this volume).

\section{Conclusions}

In this chapter, we have focused on the changing role of the multinational corporation (MNC), and of foreign direct investment (FDI), in the transformation of both individual economies and of the global economy as a whole. 'Globalisation' is viewed as a process of economic change that is both a product of, and in turn has led to, significant transformations and non-linearities in the global economy. The 'non-advanced' economies of the so-called 'Third World' have become more heterogeneous and diversified in structure and character. Economic growth has led to significant structural change, and the accelerated acquisition of capabilities in a number of these countries which, combined with effective and targeted state interventions, have led to the development of what are now termed the 'emerging economies'. These economies, in turn, have in many cases developed their own MNCs which many commentators predict are already having, or are likely to have in the future, a more beneficial impact on the development process in host less developed countries (LDCs) than more 'traditional' advanced country MNC FDI. 
It is now more difficult, and is potentially more misleading, to make broad generalisations about the process and nature of economic development and the specific impact of FDI on those processes. In many cases the broad 'meta theories' of the 1960s and 1970s, briefly referred to in the second section, now look rather dated if not plain 'wrong' in their predictions. However, we argue that there are key continuities between issues highlighted in the earlier literature and perceived real world problems in the contemporary global economy. A number of separable issues can be identified: the urgent need to create economic linkages between sectors and enterprises in host economies (in order to raise domestic value added and increase employment opportunities) and related issues of technological development, and issues relating to the tax avoidance or tax minimisation strategies pursued by many MNCs in part through the extensive use of tax-havens and the role played by, and the importance of, transfer price manipulation, in the achievement of those corporate objectives. We argue that the creation of an effective regulatory framework to deal with these problems requires a state structure with the political will, political power and competence to bargain effectively with MNCs, a set of conditions long recognised as essential but rarely achieved in practice. Although it has been out of fashion under the dictates of 'Washington Consensus' economic policies, industrial policy becomes even more important as the boundaries of the nation state are eroded by continued 'globalisation' and the autonomy of the state to pursue explicit development objectives is weakened.

The chapter briefly touched on the emergence of EMNCs, particularly Chinese enterprises which have distinct characteristics within the category of EMNCs and FDI. It is increasingly recognised that they have emerged in part as a result of strong government policies, and have developed innovative capabilities focused on the needs of low and middle income markets in the LDCs, in contradistinction to advanced country MNCs whose target tended to be higher income sectors. Whether or not the promise of EMNCs continuing to develop and serve these markets through innovative product innovation will be fulfilled remains to be seen. In the shorter run, these developments may continue as such enterprises develop and protect new markets, but this is a development which may not survive in the longer run. Future research will need to focus on the actual impact of emerging economy FDI on the development process in order to ascertain to what extent the 'promise' has been realised.

This chapter has focused mostly on FDI issues in the manufacturing sector in line with the theme of the present volume. However, we recognise that this focus has a number of unavoidable limitations. It does not discuss FDI in the extractive sectors of LDCs, which is of increasing importance to many sub-Saharan African economies where Chinese FDI has, in a relatively short space of time, established a commanding presence. It has also not dealt directly with the question of increased FDI flows into the service sectors of host economies and the impact of this on development (including so-called 'non-equity modes' of international production - refer to UNCTAD, 2011).

\section{References}

Amsden, A. H. 1989. Asia's Next Giant: South Korea and Late Industrialization. Oxford: Oxford University Press.

Amsden, A. H. 2001. The Rise of 'the Rest': Challenges to the West from Late Industrialising Countries. Oxford: Oxford University Press.

Amsden, A. H. 2009. Does Firm Ownership Matter? POEs vs. FOEs in the Developing World. In Ramamurti, R. and Singh, V. (eds.). Emerging Multinationals from Emerging Markets. Cambridge: Cambridge University Press.

Amsden, A. H. and Hikino, T. 1994. Project Execution Capability, Organizational Know-How and ConGlomerate Corporate Growth in Late Industrialization. Industrial and Corporate Change. 3 (1): 111-147. 
Azmeh, S. and Nadvi, K. 2014. Asian Firms and the Restructuring of Global Value Chains. International Business Review. 23 (4): 708-717.

Baran, P. 1957. The Political Economy of Growth. New York: Monthly Review Press.

Bartlett, C. A. and Ghoshal, S. 1987. Managing Across Borders: New Strategic Requirements. Sloan Management Review. 28 (4): 7-17.

Beugelsdijk, S., Smeets, R. and Zwinkels, R. 2008. The Impact of Horizontal and Vertical FDI on Host Country Economic Growth. International Business Review. 17 (4): 452-472.

Bhattacharya, A., Bradtke, T., Ermias, T., Haring-Smith, W., Lee, D., Leon, E., Meyer, M., Michael, D., Tratz, A., Ukon, M. and Waltermann, B. 2013. Allies and Adversaries: 2013 Global Challengers. Boston, MA: Boston Consulting Group.

Bloomström, M., Kokko, A. and Zejan, M. 2000. Host Country Competition, Labor Skills, and Technology Transfer by Multinationals. Weltwirtschaftliches Archiv. 130 (3): 521-533.

Brandt, L and Thun, E. 2010. The Fight for the Middle: Upgrading, Competition, and Industrial Development in China. World Development. 38 (11): 1555-1574.

Buckley, P. 2009. The Impact of the Global Factory on Economic Development. Journal of World Business. 44 (2): 131-143.

Buckley, P. and Casson, M. 1976. The Future of the Multinational Firm. London: Macmillan.

Buckley, P. and Ghauri, P. N. 2004. Globalisation, Economic Geography and the Strategy of Multinational Enterprises. Journal of International Business Studies. 35 (2): 81-98.

Cardoso, F. H. and Faletto, E. 1979. Dependency and Development in Latin America. Oakland: University of California Press.

Chang, H-J. 2002. Kicking Away the Ladder: Development Strategy in Historical Perspective. London: Anthem Press.

Chang, H-J. 2003. Trade and Industrial Policy Issues. In Chang, H-J. (ed.). Rethinking Development Economics. London: Anthem Press.

Colman, D. and Nixson, F. 1994. Economics of Change in Less Developed Countries, 3rd ed. Hemel Hempstead: Harvester Wheatsheaf.

Crespo, N. and Fontoura, M. 2007. Determinant Factors of FDI Spillovers - What do We Really Know? World Development. 35 (3): 410-425.

Dos Santos, T. 1973. The Crisis of Development Theory and the Problem of Dependence in Latin America. In Bernstein, H. (ed.). Underdevelopment and Development. Harmondsworth: Penguin.

Dunning, J. and Narula, R. 2004. Multinationals and Industrial Competitiveness: A New Agenda. Cheltenham: Edward Elgar.

Edwards, R., Ahmad, A. and Moss, S. 2002. Subsidiary Autonomy: The Case of Multinational Subsidiaries in Malaysia. Journal of International Business Studies. 33(1): 183-192.

Fourcade, M. 2013. The Material and Symbolic Construction of the BRICs: Reflections Inspired by the RIPE Special Issue. Review of International Political Economy. 20 (2): 256-267.

Frank, A. G. 1967. Capitalism and Underdevelopment in Latin America. New York: Monthly Review Press.

Gadiesh, O., Leung, P., and Vestring, T. 2007. The Battle for China's Good-Enough Market. Harvard Business Review. 85 (9): 71-94.

Gao, H. 2011. Changing the Rules of the Game in the New Era of Global Competition the Chinese Way. Thunderbird International Business Review. 53 (4): 539-542.

Gentile-Ludeke, S. and Giroud, A. 2012. Knowledge Transfer from TNCs and Upgrading of Domestic Firms: The Polish Automotive Sector. World Development. 40 (4): 796-807.

Gereffi, G., Humphrey, J. and Sturgeon, T. 2005. The Governance of Global Value Chains. Review of International Political Economy.12 (1): 78-104.

Hirschman, A. O. 1968. The Political Economy of Import-Substituting Industrialization in Latin America. Quarterly Journal of Economics. 82 (1): 1-32.

Hood, N. and Young, S. 1979. The Economics of Multinational Enterprise. London: Longman.

Hymer, S. 1976. The International Operations of National Firms: A Study of Direct Foreign Investment. Cambridge, MA: MIT Press.

IADB. 2013. Trade and Integration Monitor. Washington, DC: Inter-American Development Bank.

Kaplinsky, R. 2005. Globalization, Poverty and Inequality: Between a Rock and a Hard Place. Cambridge: Polity Press.

Kar, D. and Cartwright-Smith, D. 2008. Illicit Financial Flows from Developing Countries: 2002-2006. Washington, DC: Global Financial Integrity - accessible from www.gfintegrity.org 
Knickerbocker, F. 1973. Oligopolistic Reaction and Multinational Enterprise. Boston, MA: Harvard School of Business Administration.

Kokko, A., Zejan, M. and Tansini, R. 2001. Trade Regimes and Spillover Effects of FDI: Evidence from Uruguay. Weltwirtschaftliches Archiv. 137 (1): 124-149.

Lall, S. 1982. The Emergence of Third World Multinationals: Indian Joint Ventures Overseas. World Development. 10 (2): 127-146.

Lall, S. 1992. Explaining Industrial Success in the Developing World. In Balasubramanyam, V. N. and Lall, S. (eds.). Current Issues in Development Economics. London: Macmillan.

Lall, S. 2003. Technology and Industrial Development in an Era of Globalization. In Chang, H-J. (ed.). Rethinking Development Economics. London: Anthem Press.

Lall, S. and Teubal, M. 1998. 'Market Stimulating' Technology Policies in Developing Countries: A Framework with Examples from East Asia. World Development. 26 (8): 1369-1385.

Langlois, R. N. 2003. The Vanishing Hand: The Changing Dynamics of Industrial Capitalism. Industrial and Corporate Change. 12 (2): 351-385.

Levy, D. L. 2008. Political Contestation in Global Production Networks. Academy of Management Review. 33 (4): 943-963.

Lin, J. and Chang, H-J. 2009. Should Industrial Policy in Developing Countries Conform to Comparative Advantage or Defy It? A Debate Between Justin Lin and Ha-Joon Chang. Development Policy Review. 27 (5): 483-502.

Little, S. 2008. Disruptive Dragons: Can China Change the Rules of Globalization's Game? Prometheus. $26(4): 1-15$.

Luo, Y. 2004. Building a Strong Foothold in an Emerging Market: A Link Between Resource Commitment and Environment Conditions. Journal of Management Studies. 41 (5): 749-773.

Luo, Y. 2007. From Foreign Investors to Strategic Insiders: Shifting Parameters, Prescriptions and Paradigms for MNCs in China. Journal of World Business. 42: 14-34.

Luo, Y. and Tung, R. L. 2007. International Expansion of Emerging Market Enterprises: A Springboard Perspective. Journal of International Business Studies. 38 (4): 481-498.

Meyer, K. E., and Sinani, E. 2009. When and Where Does Foreign Direct Investment Generate Positive Spillovers? A Meta-Analysis. Journal of International Business Studies. 40 (7): 1075-1094.

Miozzo, M. and Yamin, M. 2012. Institutional and Sectoral Determinants of Headquarters-Subsidiary Relationships: A Study of UK Service Multinationals in China, Korea, Brazil and Argentina. Long Range Planning. 45 (1): 16-40.

Mirza, H. and Giroud, A. 2004. Regionalization, Foreign Direct Investment and Poverty Reduction. Journal of the Asia Pacific Economy. 9 (2): 223-248.

Morrissey, O. 2012. FDI in Sub-Saharan Africa: Few Linkages, Fewer Spillovers. European Journal of Development Research. 24 (1): 26-31.

Nam, K-M. and Li, X. 2013. Out of Passivity: Potential Role of OFDI in IFDI-Based Learning Trajectory. Industrial and Corporate Change. 22(3): 711-743.

Narula, R. and Driffield, N. 2012. Does FDI Cause Development? The Ambiguity of the Evidence and Why it Matters. European Journal of Development Research. 24 (1): 1-7.

Nolan, P., Sutherland, D., and Zhang, J. 2002. The Challenge of the Global Business Revolution. Contributions to Political Economy. 21 (1): 91-110.

Nolan, P., Zhang, J. and Liu, C. 2008. The Global Business Revolution, the Cascade Effect, and the Challenge for Firms from Developing Countries. Cambridge Journal of Economics. 32 (1): 29-47.

Palan, R., Murphy, R. and Chavagneux, C. 2010. Tax Havens: How Globalization Really Works. Ithaca, NY: Cornell University Press.

Palma, G. 1978. Dependency: A Formal Theory of Underdevelopment or a Methodology for the Analysis of Concrete Situations of Underdevelopment? World Development. 6 (7/8) July/August: 881-924.

Perrow, C. 2009. Modeling Firms in the Global Economy. Theory and Society. 38 (3): 217-243.

Ramamurti, R., and Singh, J. V. (eds.). 2009. Emerging Multinationals in Emerging Markets. Cambridge: Cambridge University Press.

Rodriguez-Clare, A. 1996. Multinationals, Linkages, and Economic Development. American Economic Review. 86 (4): 852-873.

Sanchez-Ancochea, D. 2006. Development Trajectories and New Comparative Advantages: Costa Rica and the Dominican Republic Under Globalization. World Development. 34 (6): 996-1015.

Sell, S. K. 2003. Private Power, Public Law: The Globalization of Intellectual Property Rights. Cambridge: Cambridge University Press. 
Shaxson, N. 2011. Treasure Islands: Tax Havens and the Men Who Stole the World. London: Bodley Head.

Sikka, P. and Willmott, H. 2013. The Tax Avoidance Industry: Accountancy Firms on the Make. Critical Perspectives on International Business. 9 (4): 415-443.

Sinkovics, R., Yamin, M., Nadvi, K. and Zhang, Y. 2014. Rising Powers from Emerging Markets - The Changing Face of International Business. International Business Review. 23 (4): 675-679.

Stewart, F. 1977. Technology and Underdevelopment. London: Macmillan.

Sunkel, O. 1969. National Development Policy and External Dependence in Latin America. Journal of Development Studies. 6 (1): 23-48.

Sunkel, O. 1973. The Pattern of Latin American Dependence. In Urquidi, V. and Thorp, R. (eds.). Latin America in the International Economy. London: Macmillan.

UNCTAD. 1992. World Investment Report: Transnational Corporations as Engines of Growth. New York: United Nations.

UNCTAD. 2001. World Investment Report: Promoting Linkages. New York: United Nations.

UNCTAD. 2003. World Investment Report: FDI Policies for Development: National and International Perspectives. New York: United Nations.

UNCTAD. 2011. World Investment Report: Non-Equity Modes of International Production and Development. New York: United Nations.

UNCTAD. 2012. World Investment Report: Towards a New Generation of Investment Policies. New York: United Nations.

UNCTAD. 2013. World Investment Report: Global Value Chains and Trade for Development. New York: United Nations.

UNCTAD. 2014. World Investment Report: Investment in the Sustainable Development Goals. New York: United Nations.

Vaitsos, C. 1974. Intercountry Income Distribution and Transnational Enterprises. Oxford: Clarendon Press.

Wade, R. 1990. Governing the Market: Economic Theory and the Role of Government in East Asian Industrialization. Princeton, NJ: Princeton University Press.

Wade, R. 2003. What Strategies are Viable for Developing Countries Today? The World Trade Organization and the Shrinking of 'Development Space'. Review of International Political Economy. 10 (4): 621-644.

Weiss, L. 2010. The State in the Economy: Neoliberal or Neo-Activist? In Morgan, G., Campbell, J., Crouch, C., Pedersen, O. K. and Whitley, R. (eds.). The Oxford Handbook of Comparative Institutional Analysis. Oxford: Oxford University Press.

Williamson, P., Ramamurti, R., Fleury, A. C. C. and Fleury, M. T. L. 2013. The Competitive Advantage of Emerging Market Multinationals. Cambridge: Cambridge University Press.

Xu, B. 2000. Multinational Enterprises, Technology Diffusion, and Host Country Productivity Growth. Journal of Development Economics. 62 (2): 477-493.

Yamin, M. 1983. Direct Foreign Investment as an Instrument of Corporate Rivalry: Theory and Evidence from the LDCs. In Kirkpatrick, C. H. and Nixson, F. I. (eds.). The Industrialization of Less Developed Countries. Manchester: Manchester University Press.

Yamin, M. 2000. A Critical Re-Evaluation of Hymer's Contribution to the Theory of International Operations. In Pitelis, C. and Sugden, R. (eds.). The Nature of the Transnational Firm. London: Routledge: 57-71.

Yamin, M. 2011. A Commentary on Peter Buckley's Writings on the Global Factory. Management International Review. 51 (2): 285-293.

Yamin, M. and Forsgren, M. 2006. Hymer's Analysis of the Multinational Organization: Power Retention and the Demise of the Federative MNE. International Business Review. 15 (2): 166-179.

Yamin, M. and Sinkovics, R. R. 2009. Infrastructure or Foreign Direct Investment? An Examination of the Implications of MNE Strategy for Economic Development. Journal of World Business. 44 (2): 144-157.

Zanfei, A. 2005. Globalization at Bay? Multinational Growth and Technology Spillover. Critical Perspectives on International Business. 1 (1): 5-17. 